\title{
Geomorphic-centered Classification of Wetlands on the Qinghai-Tibet Plateau, Western China
}

\author{
GAO Jay $^{1 *}$, LI Xi-lai ${ }^{1,2}$, Gary BRIERLEY ${ }^{1}$, Alan CHEUNG', YANG Yuan-wu² \\ 1 School of Environment, University of Auckland, Private Bag 92019, Auckland, New Zealand \\ 2 College of Agriculture and Animal Husbandry, Qinghai University, Xining 810o16, China \\ ${ }^{*}$ Corresponding author, e-mail:jg.gao@auckland.ac.nz
}

(C) Science Press and Institute of Mountain Hazards and Environment, CAS and Springer-Verlag Berlin Heidelberg 2013

\begin{abstract}
In this paper a geomorphic-centered system was proposed for classifying the wetlands on the Qinghai-Tibet Plateau in western China, where the flora comprises primarily grasses. Although the geomorphic properties (e.g., elevation and morphology) of wetlands form the primary criteria of classification, this system also takes hydrological processes into implicit consideration. It represents an improvement over the hydrogeomorphic perspective as the relative importance of the two components (wetness and landform) of wetlands is clearly differentiated. This geomorphic-centered perspective yields insights into the hydrogeomorphic dynamics of plateau wetlands while indicates their vulnerability to change and degradation indirectly. According to this geomorphic-centered perspective, all plateau wetlands fall into one of the seven types of alpine, piedmont, valley, terrace, floodplain, lacustrine, and riverine in three elevational categories of upland, midland, and lowland. Upland (alpine and piedmont) wetlands with the steepest topography are the most sensitive to change whereas midland (floodplain, terrace and valley) wetlands are less vulnerable to degradation owing to a high water reserve except terrace wetlands. They have a dry surface caused by infrequent hydrological replenishment owing to their higher elevation than the channel. Low lying (lacustrine and riverine) wetlands are the most resilient. The geomorphic-centered perspective developed in this paper provides a framework for improving recognition and management of wetlands on the Plateau. Resilient wetlands can be grazed more intensively without the risk of degradation. Fragile and vulnerable wetlands require careful management
\end{abstract}

Received: 15 October 2012

Accepted: 16 January 2013 to avoid degradation.

Key words: Plateau wetlands; Geomorphic classification; Wetland vulnerability; Qinghai-Tibet Plateau

\section{Introduction}

The Qinghai-Tibet Plateau is the world's largest, covering an area of $1,000 \mathrm{~km}$ by $2,500 \mathrm{~km}$. With an elevation ranging from 3,000 to $5,000 \mathrm{~m}$ a.s.l., it is also the highest plateau on earth. Its nickname as the "roof of the world" derives probably from its mean elevation of $4,320 \mathrm{~m}$. The Plateau is characterized by low annual temperatures with a typical continental alpine climate. It receives an annual rainfall of 100 to 300 $\mathrm{mm}$ that occurs mostly as hail storms in summer (June-September) and snow in winter. A mean annual temperature of $-4^{\circ} \mathrm{C}$ is translated into a short growing season of three-four months. The surface soils are frozen for much of the year and permafrost occurs just a few meters below the surface. On the other hand, there is plenty of solar energy available, with annual sunshine totalling 2,260 hours (Zhou et al. 2003), and total solar radiation accumulating to 150-190 kilo-calories/ $\mathrm{cm}^{2}$ per annum (Zheng et al. 1979). Vegetative cover of the Plateau is dominated by grasslands. Plains of highland meadows and steppes are interspersed with bare or grass-covered mountain ranges of a relief around $700 \mathrm{~m}$ while marshy 
meadows are distributed in the lower valleys.

Despite its arid to semi-arid climate, the Qinghai-Tibetan Plateau is nicknamed the "water tower of China" because abundant water is generated from snow melting. It replenishes a variety of wetlands on the Plateau. These plateau wetlands are located at an elevation between 3,200 and 4,500 $\mathrm{m}$ a.s.l. (Zhou et al. 2005). Apart from the usual wetlands associated with rivers and lakes in lowland areas, there are also extensive swampy meadows that total 510,000 ha in the headwater region of the Yellow and Yangtze Rivers alone (Zhou et al. 2005). They are commonly distributed in the low depressions of broad valleys, basins, the peripheries of proluvial fans with a ground water level at 20-40 cm (Wang 2000). Unlike wetlands elsewhere, wetlands on the Plateau have a flora dominated by hydrophytes and mesohydrophytes such as Kobresia tibetica, Blysmus sinacompressus, and Carex scabriostris of 20-25 $\mathrm{cm}$ in height (Zhou et al. 2005).

Plateau wetlands have a number of unique features that compel us to study and classify them. Firstly, they are inherently fragile in this arid and semi-arid environment. Except those wetlands associated with rivers and lakes, most plateau swamps have a limited water reserve in the form of shallow ponds. There is limited rainwater and runoff in this arid and semi-arid environment to replenish groundwater reserves annually. The low water reserves may be depleted quickly by outflow and evaporation, causing the wetlands susceptible to desiccation. Once the sedge mats in a wetland dry out, it is subject to the invasion of plateau pikas that are absent in waterlogged swamps (Miehe et al. 2011). These small mammals dig burrows on the ground and are an active agent in causing and accelerating soil erosion. Secondly, they are subject to frequent and sometimes intensive anthropogenic activities (Zhou et al. 2005). Plateau wetlands, in the forms of marshy and swampy meadows, offer nutritious species of grasses for the livestock. They are hence an important contributor to local animal husbandry. In comparison with dry grasslands on the Plateau, such grass-dominated meadows are heavily grazed, especially during the winter season (Miehe et al. 2011). Overgrazing has been identified as one of the causes for wetland degradation (Zhou et al. 2003). Lastly, plateau wetlands are sensitive to external environmental change. A warmer climate accelerates snow melting and permafrost thawing on the one hand. On the other, it also precipitates depletion of water and moisture through more evaporation. Given the inherent fragility of wetlands on the Plateau (i.e., a relatively small groundwater reserve, limited water resources for replenishment, and increased water loss due to climate change), it is important to study and protect plateau wetlands. Protection of plateau wetlands is significant not only to the sustainability of the local animal husbandry and the livelihood of local herdsmen, but also to maintaining a sound ecosystem and minimizing soil erosion in the source region of the Yangtze, Yellow and Mekong Rivers. Besides, it also has profound repercussions on channel morphology and downstream water quality beyond the watershed. The development of a classification system for plateau wetlands that is indicative of their vulnerability to change and degradation is a prerequisite for and preparatory step towards their effective management and protection.

\section{Wetland Classification Schemes and Criteria}

Wetland classification for inventory purposes has been a topic of international interest (Hefner and Storrs 1994; Robertson and Fitzsimons 2004; Clausen et al. 2006). So far a few classification systems have been devised for inventorying wetlands in various parts of the world, each having its own strengths and limitations, and applicable to a specific geographic region. Some of the well known systems are Ramsar, Cowardin, the Canadian, and New Zealand systems. In the Ramsar System, the main types of wetlands fall into four categories of marine, coastal, inland, and artificial. This scheme is of limited utility in wetland inventory (Costa et al. 1996) because wetland types under different sub-categories are not mutually exclusive owing to the indistinctive boundaries between them. The Cowardin system (Cowardin et al. 1979) is one of the most comprehensive and versatile wetland classification systems because it is structured into sub-systems, classes and sub-classes (Finlayson and van der Valk 1995). This hierarchical structure is composed of five major systems (marine, estuarine, riverine, 
lacustrine, and palustrine) distinguishable by a variety of hydrologic, geomorphologic, chemical, and biological characteristics. Despite its adoption as the National Vegetation Classification Standard for wetlands in the US, its applicability elsewhere is yet to be tested. Others have designed their own systems, such as the Environmental Council wetland classification system (Thompson 1987) for use with the New Zealand Wetland Management Policy and the Wetlands of Ecological and Regional Interest database. It encompasses hydroclasses of marine, estuarine, lagoon, riverine, and lacustrine. Although comprehensive and simple to comprehend, the system has differential levels that are not consistently developed. Such deficiencies are overcome by the UNEP GRID New Zealand Wetland Classification system (Ward and Lambie 1999). This more rational and scientific system incorporates the best elements of new classification practice overseas. Nevertheless, it is inapplicable to the plateau environment. Recently, Brooks et al. (2011) adopted a hydrogeomorphic approach in classifying wetlands in the Mid-Atlantic region of the US. It recognizes the important role that geomorphic setting, water sources and flow dynamics play in the healthy functioning of wetlands. Nevertheless, this approach targets estuarine wetlands only, and are ill suited to plateau wetlands.

The above discussion demonstrates that a wide range of criteria have been used for wetland classification, such as landform settings, origins, substrates, hydrology (Robertson and Fitzsimons 2004), water quality, and vegetation. The classification criteria common to these systems include environmental factors (e.g., nature of water, amount of water, soil fertility, and soil acidity), vegetation pattern and form (Semeniuk et al. 1990), topography, floristics, substrate types, nutrient status (Thompson 1987), and species composition (Brinson 1993). It must be noted that not all of these criteria are suitable for the plateau environment as they may be spatially uniform, especially at a local scale. For instance, there is little spatial variation in vegetation types on the Plateau. On the other hand, local morphology (e.g., elevation) is instrumental in determining the distribution of water and moisture on a slope and in the watershed in the plateau environment. Of these criteria, the geomorphic-hydrologic one has been exploited to classify wetlands by several authors. Brinson (1993) classified wetlands into depressional, riverine, mineral flats, organic flats, tidal fringe, lacustrine fringe, and slopes based on their geomorphic setting, water source, and hydrodynamics. This geomorphic-hydrologic criterion provides a framework for determining wetland conditions, and is modifiable for specific wetland types in specific areas. As the classification serves to lay the ground work for assessing the functions of wetlands, this hydrogeomorphic approach does not shed any light on the health and vulnerability of the wetlands. Later, Stander and Ehrenfeld (2009) applied this hydrogeomorphic approach to quickly assess the functions of urban wetlands. This hydrogeomorphic perspective is appealing for its ability to link ecological functions of a wetland to the determinants of water flow. Espinar and Serrano (2009) further refined the hydrogeomorphic criteria in classifying wetlands by introducing a quantitative threshold to them. However, discrimination within each wetland type is not always successful. This outcome is anticipated given that hydrogeomorphic classifications by their very nature are not designed to be sensitive to species composition of vegetation (Brinson 1993). Since vegetation on the Plateau has a homogeneous composition of mostly Kobresia littledalei swampy meadows, these classifications are quite suited to plateau wetlands, and thus adopted in this paper.

\section{Geomorphic-centered Classification Scheme}

Essential to the hydrogeomorphic classifications are two primary components of wetlands, 'wetness' and 'landform', both of which determine their dimension, shape and depth. Subdivision of cross-sectional landform geometry resulted in three types of wetland (basins, channels, and flats), further dividable by water longevity (Semeniuk 2007). It must be emphasized that the two components of wetlands are by no means independent of each other. Location in the watershed (topographic position) and relationship to the principal zone of saturation (hydrologic position) are identified as the two key physical properties of wetlands and landscapes controlling 
several hydrologic functions (O'Brien 1988). Therefore, it is important not to double count the role of the same criterion in the classification. Moreover, this relationship suggests that the two components are not equally important in forming and maintaining wetlands on the Plateau, and hence in indicating their state, especially their potential for degradation. This hydrogeomorphic perspective on wetland classification is thus slightly modified to the geomorphic-centered perspective to reflect the more important role morphology plays in the formation of plateau wetlands. Although this perspective does not contain hydrology in its name, the effect of hydrology is still taken into consideration implicitly via its inalienable association with morphology at the hillslope and watershed scales. Geomorphology strongly influences local patterns of water movement, e.g., surface drainage and groundwater flow, and determines the degree to which wetlands are open to lateral movement of water. Geomorphology and position in landscape stratify wetlands according to their landform and relationship to surrounding landforms (Bedford and Preston 1988). Similar to that used in a descriptive classification by Semeniuk (1987), this perspective emphasizes the forms of the land surface and the processes producing them (Forman and Godron 1986). It is economical to make use of only geomorphology in the classification as the use of too many descriptors of wetland ecosystems and disturbances to them is neither efficient nor feasible, especially in impact assessments, monitoring schemes, or management planning (Bedford and Preston 1988). This geomorphic-centered

perspective is considered appropriate for the plateau setting where morphology plays a decisive role in governing the (re)distribution of water and moisture on a slope and in the catchment. Under this geomorphiccentered perspective, all wetlands on the Plateau are profile. classified as alpine, valley, piedmont, terrace, floodplain, lacustrine, and riverine.

\subsection{Alpine wetlands}

Alpine wetlands are highland marshes situated in the middle to lower section of the mountain side with a mean elevation around 4,310 $\mathrm{m}$ a.s.l., the highest among all types of plateau wetlands (Table 1). At such a high elevation, they also have the steepest (18.4\%) slope gradient. This association with the sides of individual mountains makes alpine wetlands rather small (e.g., tens of square meters) in size (Figure 1). These marshes have an irregular shape whose exact form is dictated by the local morphology. They have a V-shaped crosssection and $J$-shaped profile. Their lower elevation than the immediate surroundings causes water to converge in the marshes. Also alpine wetlands collect water from higher grounds via subsurface drainage of water from snow and ice melting, infrequent surface runoff, and the annual thawing of permafrost. Their high elevation in the landscape causes their catchment size to be rather small accordingly. Thus, alpine wetlands tend to have a low water reserve. The accumulated water is insufficient to form small pools that are characteristics of plateau marshes. Occasionally, there are tiny streams running through alpine wetlands (Figure 1). Recharge to alpine wetlands is restricted to the rainy season or summer when

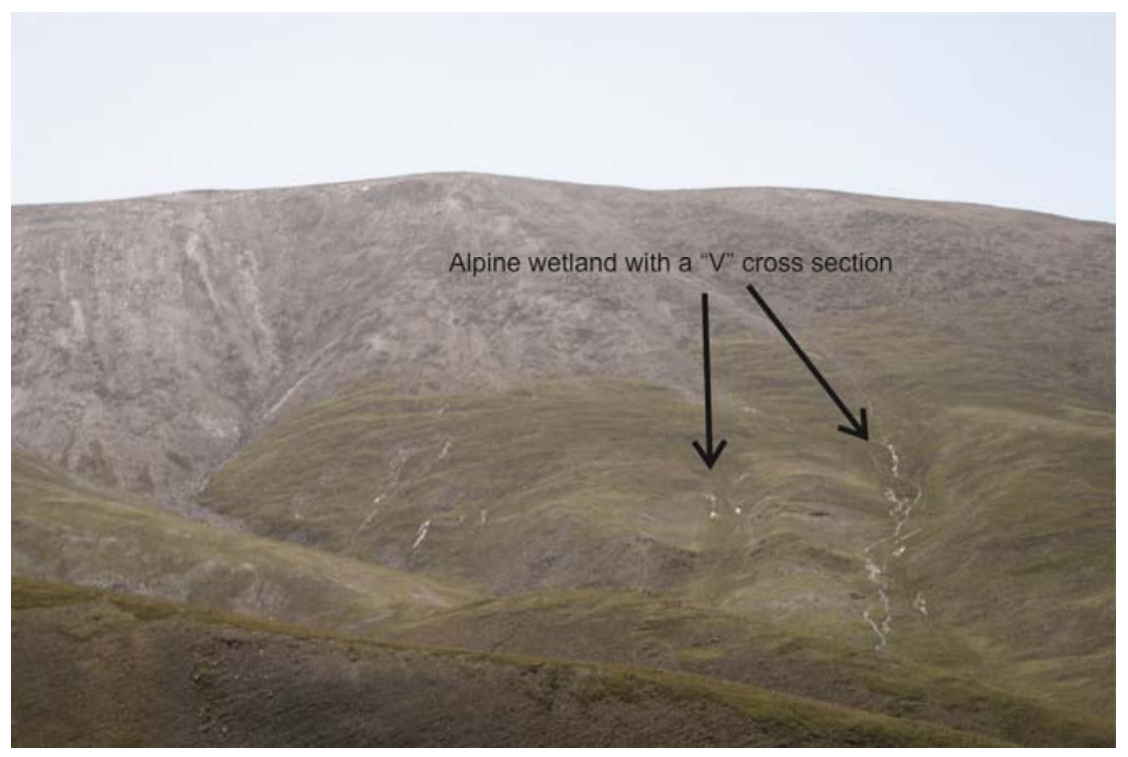

Figure 1 Alpine wetland located in the middle to low hillslope of a mountain. Its geomorphic feature is characterized by a V-shaped cross section and a J-shaped 
Table 1 Summary of major plateau wetland types, their geomorphic and hydrological characteristics, and typical grass species.

\begin{tabular}{|c|c|c|c|c|c|}
\hline Type & Position & $\begin{array}{l}\text { Mean elevation } \\
\text { (m a.s.l.)* }\end{array}$ & $\begin{array}{l}\text { Slope } \\
(\%)\end{array}$ & Hydrology & Typical grasses \\
\hline Alpine & \multirow[b]{2}{*}{ Upland } & 4,310 & 18.4 & $\begin{array}{l}\text { Moist ground formed } \\
\text { by percolated water }\end{array}$ & Kobresia pygmaea \\
\hline Piedmont & & 4,269 & 10.4 & $\begin{array}{l}\text { Ponds of water } \\
\text { recharged via sub- } \\
\text { surface flow }\end{array}$ & $\begin{array}{l}\text { Kobresia tibetica Maximowicz, Pedicularis } \\
\text { chinensis, Kobresia humilis, Elymus } \\
\text { dahuricus Turcz }\end{array}$ \\
\hline Valley & \multirow{3}{*}{ Midland } & 4,252 & 4.2 & $\begin{array}{l}\text { Saturated ground \& } \\
\text { pocket of water }\end{array}$ & $\begin{array}{l}\text { Kobresia pygmaea, Kobresia tibetica, } \\
\text { Kobresia capillifolia, Poa annua linn }\end{array}$ \\
\hline Terrace & & 4,248 & 4.9 & $\begin{array}{l}\text { Wet ground by } \\
\text { overland flow }\end{array}$ & $\begin{array}{l}\text { Kobresia tibetica, Pedicularis chinensis, } \\
\text { Poa annua linn, Ligularia } \\
\text { virgaurea(Maxim.)Mattf. Artemisia }\end{array}$ \\
\hline Floodplain & & 4,243 & 1.5 & $\begin{array}{l}\text { Extensive wet surface, } \\
\text { small pools of water }\end{array}$ & $\begin{array}{l}\text { Kobresia tibetica, Ligularia virgaurea, } \\
\text { Leontopodium alpinum, Ligularia } \\
\text { virgaurea Artemisia }\end{array}$ \\
\hline Lacustrine & \multirow{2}{*}{ Lowland } & 4,230 & 1.0 & $\begin{array}{l}\text { Shallow lake peripheral } \\
\text { areas, lakeshore of } \\
\text { saturated ground }\end{array}$ & $\begin{array}{l}\text { Polygonum spp. Carex, } \\
\text { Glaux maritime sibiricum Laxm, } \\
\text { Polygonum sibiricum Laxm }\end{array}$ \\
\hline Riverine & & 4,221 & 4.9 & $\begin{array}{l}\text { Elongated stagnant } \\
\text { channels }\end{array}$ & $\begin{array}{l}\text { Kobresia tibetica (Polygonum spp.) } \\
\text { Artemisia spp., Poa annua Linn, } \\
\text { Elymus dahuricus Turcz, Carex }\end{array}$ \\
\hline
\end{tabular}

Note:* means measured with a Garmin GPSmap 60 CSx receiver in the stationary mode during August 2011. The number of measurements used in calculating the mean varies with wetland types.

snow is melting and permafrost thawing. Recharge during spring is limited in lower mountain ranges where there is scant snow accumulation over winter. For this reason alpine wetlands have the largest chance of being seasonal (e.g., in summer) among all plateau wetlands.

\subsection{Piedmont wetlands}

Piedmont wetlands are highland marshes located at the transitional zone between the foot of mountains or a mountain range and a floodplain/terrace in their

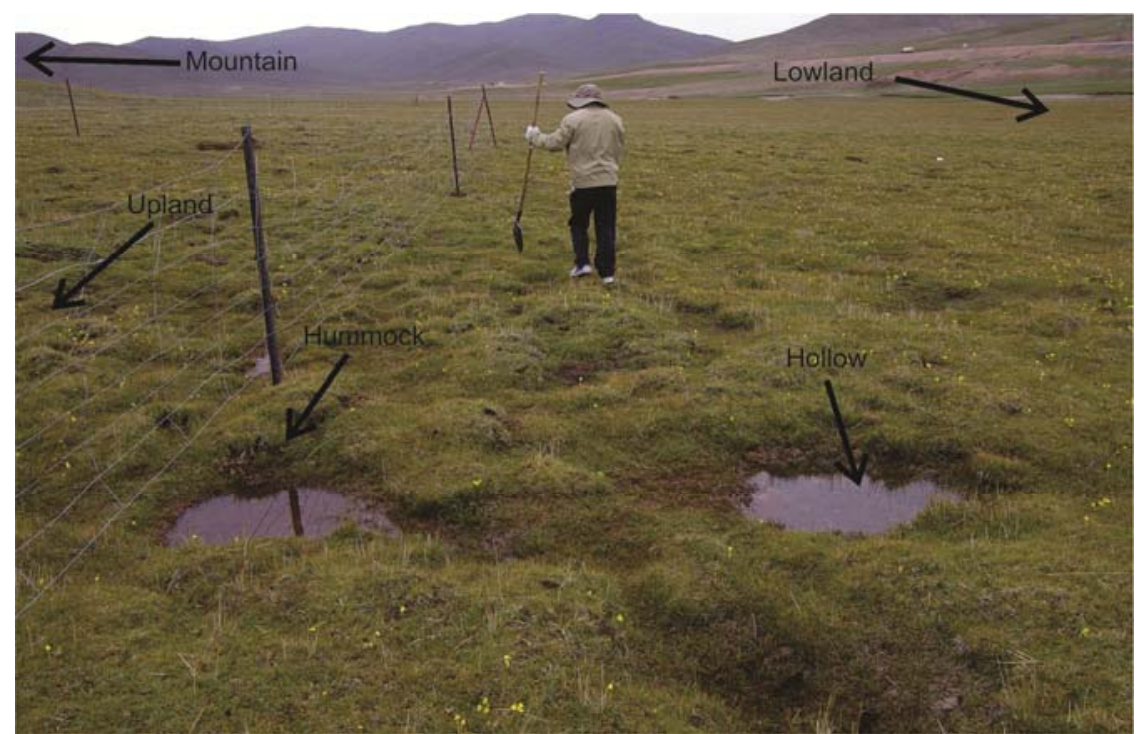

Figure 2 Piedmont wetland is located between the foot of a mountain or mountain range and other geomorphic features such as a floodplain or terrace. Distributed within piedmont wetlands are small pools of water and hummocks. lower side with a mean

elevation of 4,269 m a.s.l. (Figure 2). Despite their close spatial adjacency, piedmont and alpine wetlands are easily distinguishable from each other in elevation and surface gradient (Table 1). On average, piedmont wetlands are about $40 \mathrm{~m}$ lower than alpine wetlands. More importantly, their surface has a lower gradient of $10.4 \%$, much gentler than alpine wetlands. Spatially, piedmont wetlands are more expansive than alpine wetlands, even though their exact size varies with the mountain ranges. Distributed within piedmont wetlands are small pools of water and hummock-and-hollow surface formed by the melting of ice (Figure 2). Hydrologically, they are replenished by subsurface flow of water over a hillslope. A moderate to steady subsurface flow of water, percolated down the 
surface, takes place downhill under the effect of gravity. Thus, seepage of subsurface moisture over a slope is the dominant means of recharge to piedmont wetlands. The water reserve in a piedmont wetland varies temporally. In the warm season when snow melting and ground thawing are active, the ground is fully saturated with water. This water reserve is lowered by evaporation and outflow to lower grounds.

\subsection{Valley wetlands}

Valley wetlands are plateau marshes distributed on valley floors flanked by a mountain range

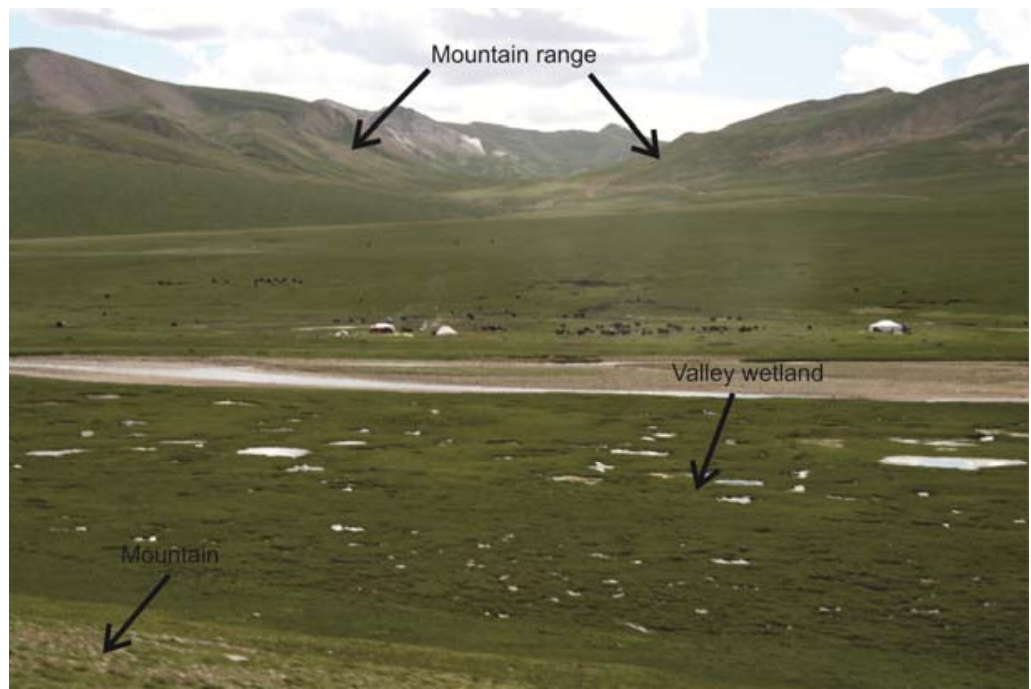

Figure 3 The narrow and elongated valley wetland flanked by mountains on both sides. The rich moisture content makes the grass healthier than the surrounding dry grassland.

\section{on both sides, or partially encircled}

by mountains if they merge at one end (Figure 3). They are not depressional wetlands as the valleys are never fully enclosed. Having a mean elevation of 4,252 m a.s.l., valley wetlands are slightly lower than piedmont wetlands. Unlike alpine wetlands that are linked to individual hillslopes, valley wetlands are commonly associated with multiple mountains or mountain ranges. The exact dimension of valley wetlands is controlled by the space between mountains or mountain ranges. They have a larger dimension if flanked by mountain ranges than those flanked by singular mountains. Also, it is possible for one valley wetland to join another when two mountain ranges intersect with each other, usually at an angle close to $90^{\circ}$. In either case the valley floor has a flat topography or very gentle slope with a gradient of 4.2\% (Table 1). As such, valley wetlands are characterized by a linear form and a rectangular shape with their orientation trending that of the mountain ranges. Valley wetlands are nourished by surface runoff from higher grounds or water seepage from the flanking mountains. Owing to their large catchment area, valley wetlands usually have small pools of water distributed amid them (Figure 3). Such water seldom flows because of the absence of a clear channel and the low gradient. As is the case with alpine and piedmont wetlands, the rich moisture makes the swampy grasses of Kobresia pygmaea, Kobresia tibetica, and Kobresia capillifolia much more thriving than the surrounding dry grasslands. The slow pace of water depletion means that valley wetlands are more likely to be perennial than seasonal.

\subsection{Terrace wetlands}

River terrace refers to a bench or step along the side of a valley. It can be the former valley floor after the river has incised the channel to form a new floodplain as a result of changed hydrologic or climate regime, or tectonic uplift. Terrace wetlands are thus defined as marshes located in a terrace (Figure 4). Adjoining terrace wetlands is a major channel with a small difference in elevation between the water level in the channel and the terrace surface. Despite their close similarity in appearance, terrace wetlands and piedmont wetlands are readily distinguishable from each other by topography, proximity to rivers and hydrology. Topographically, terrace wetlands have a mean elevation of 4,248 $\mathrm{m}$ a.s.l., much lower than piedmont wetlands. Besides, their surface is very gently sloping with a gradient of $4.9 \%$, much flatter than that of piedmont wetlands. Geographically, terrace wetlands usually separate piedmont wetlands from the channel. In fact, terrace wetlands lie in close proximity to the river channel (e.g., a distance $<10 \mathrm{~m}$ ). Hydrologically, terrace wetlands are recharged by overland flow of water from a higher ground. This contrasts with the subsurface flow of moisture from the slopes above 


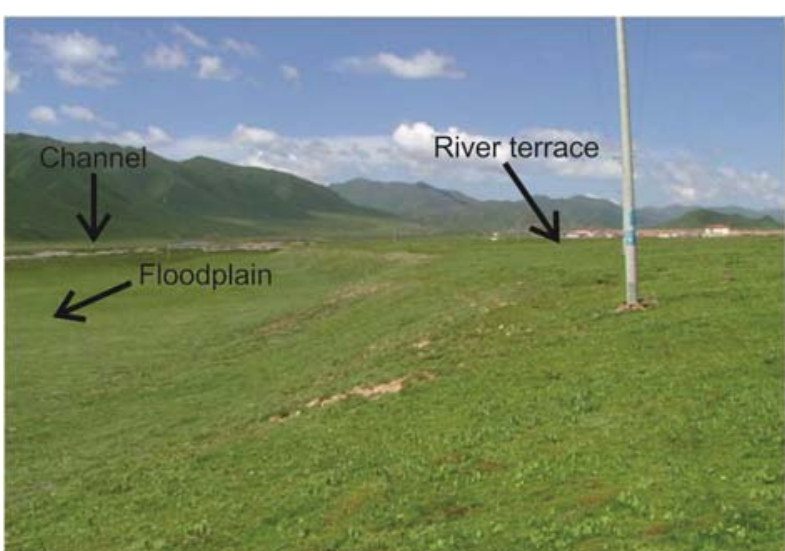

Figure 4 Relationship between terrace wetland and its proximity to river channel.

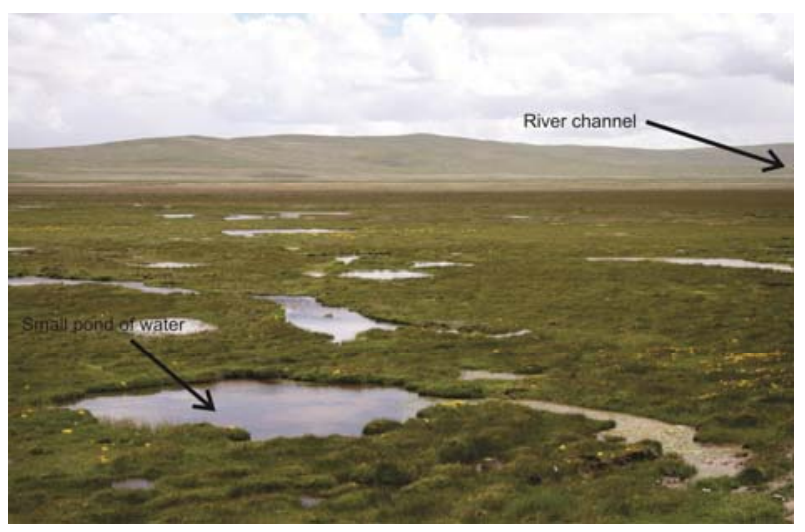

Figure 5 Floodplain wetland is located in a close proximity to a river channel. Its surface may be covered by pools of water.

for piedmont wetlands. Terrace wetlands are infrequently replenished by river water because their higher elevation than the river channel nearby is difficult for the river water to reach them unless during flooding. They are also remote from other water sources of recharge (e.g., they are separated from the mountains by piedmont wetlands). Consequently, terrace wetlands are the driest among all wetland types. No accumulation of surface water is visible except a moist ground (Figure 4). Associated with this dryness are the drought-tolerant species of Pedicularis chinensis, Poa annua linn, Ligularia virgaurea (Maxim.) Mattf, and Artemisia (Table 1).

\subsection{Floodplain wetlands}

Floodplain is an extensive, flat area lying between a river channel and a mountain.
Floodplain wetlands hence refer to swamps located in a flat, spatially expansive floodplain (Table 1). Such wetlands are replenished by river water during floods via overland or overbank flow. Commonly dotted with relatively large pools of varying sizes (Figure 5), floodplain wetlands have a much larger water reserve than any of the above types of wetlands on the Plateau. Although floodplain wetlands may resemble piedmont wetlands sometimes, the two are distinguishable by their surface topography and soundings. Floodplain swamps have a mostly flat surface (a mean gradient of only $1.5 \%$ ), in drastic contrast to piedmont wetlands that have a general sloping surface from upland to lowland (Table 1). If a floodplain lies next to a mountain, a floodplain wetland may be confused with valley wetlands occasionally. This confusion can be avoided by the fact that floodplain swamps are never confined between two mountains or mountain ranges. Besides, they do not share the rectangular shape of valley marshes. Moreover, floodplain wetlands are located at a lower $(4,243 \mathrm{~m})$ mean elevation where the channel carries more discharge from the much wider catchment. In addition, they are recharged by different hydrologic processes. Floodplains have an inherent connection with rivers hydrologically (Kingsford 2000), just like terrace wetlands. As such, floodplain wetlands are lavishly replenished by river water, and most likely permanent.

\subsection{Lacustrine wetlands}

Lacustrine wetlands are defined as swamps associated with the shallow part of a lake where aquatic vegetation or water-tolerant plants are growing amidst water (Figure 6). Since the plateau flora comprises invariably grasses or low shrubs, the presence of stagnant water is the distinguishing characteristic of lacustrine wetlands. In addition, lacustrine wetlands can be grounds immediately next to the lakeshore or in the vicinity of a channel joining the lake. The terrestrial section of lacustrine wetlands has a belt shape along the shore where the ground is saturated with water. Occasionally, small ponds of water are distributed among it. Both the aquatic and terrestrial sections of lacustrine wetlands are replenished by the lake water. As such, they are subject to the fluctuation of the lake water level, and interchangeable 
between them. At a low level more of the lake floor is exposed, turning the lake into terrestrial wetlands, and vice versa. The newly created wetlands may be covered with vegetation that has withered or even perished after extended submerging in the water. Conversely, more onshore wetland is inundated by the lake water to become aquatic at a higher water level. If the water level continues to rise, then the wetland will eventually disappear to form part of the enlarged lake.

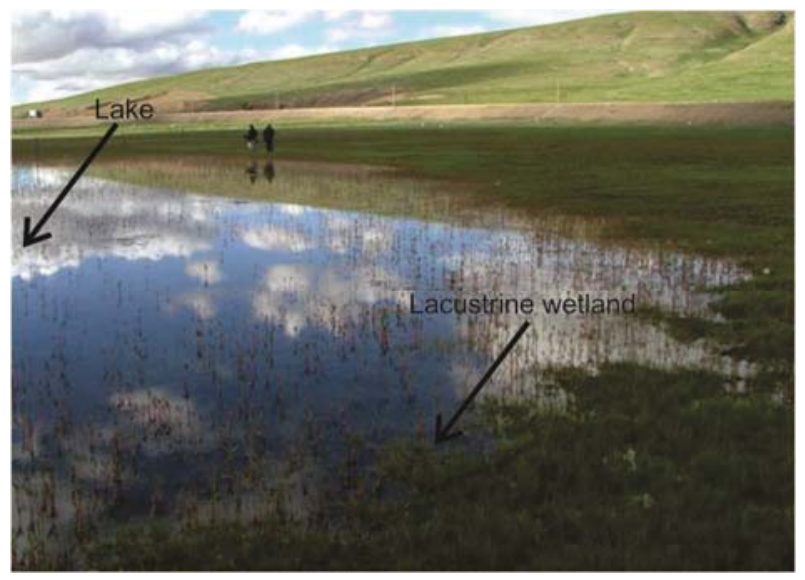

Figure 6 Lacustrine wetland is commonly found at the periphery of a lake.

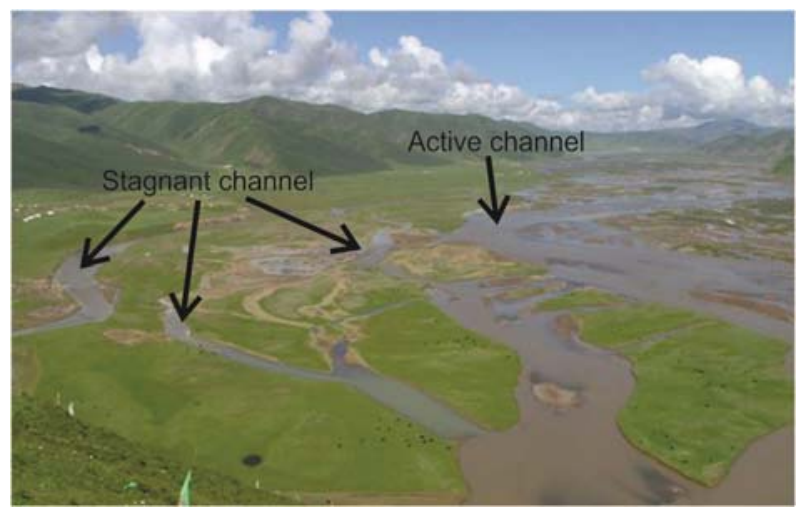

Figure 7 Riverine wetland is located inside a braiding or (ana) branching but inactive channel.

If the lake is located next to a mountain, then the distinction between piedmont and terrestrial lacustrine wetlands becomes blurry. Topographically and biologically, however, the two can still be differentiated from each other. Lacustrine wetlands are located at 4,230 $\mathrm{m}$ a.s.l., much lower than piedmont marshes. They have a gentler gradient (only 1\%) consistent with that of lake floor, in sharp contrast to the steep surface
(10.4\%) of piedmont wetlands. The exact boundary between the two can also be demarcated by the type of vegetation present. The presence of watertolerant species such as Polygonum spp, Glaux maritime sibiricum Laxm, Carex Polygonum sibiricum Laxm signifies the extent of lacustrine wetlands (Table 1). Hydrologically, they also differ from each other. Unlike piedmont wetlands, terrestrial lacustrine wetlands are recharged by rain water from a higher ground via overland flow, or by lake water. Consequently, they have a larger water reserve, and are highly resistant to change.

\subsection{Riverine wetlands}

As the name implies, riverine wetlands are swamps related to river channels. In the plateau environment these channels are freely wandering, and frequently (ana) branching and braiding. Sandwiched between two braiding channels are elongated islands of grasslands or riverine wetlands (Figure 7). These channels are usually a dysfunctional branch or tributary that is not actively involved in discharging channel flow. The inclusion of such inactive channels in riverine wetlands makes it difficult to separate wetlands from water bodies. Riverine wetlands have the lowest elevation of $4,220 \mathrm{~m}$ a.s.l. among all types of wetlands. They have a surface gradient of less than $5 \%$ (Table 1). The channel bed has a small gradient from the upper reach to the lower reach, as well. This gentle gradient makes the water inside the wetlands stagnant or flow at a very slow speed. This means that the water reserve is not easily depleted through outflow. Similar to aquatic lacustrine wetlands, riverine wetlands contain extensive pools of water within them, some of which can be rather deep. This large water reserve is replenished by variable mechanisms of water exchange between the active channel and the dysfunctional branch in this parafluvial zone. The exact means of recharge depends on the distance from the active channel and the nature of channel branching. The only exception is during flooding when all are replenished equally. Similar to lacutrine wetlands, riverine wetlands are also subject to the influence of the water level. Riverine wetlands shrink at a higher water level, and vice versa. The surface appearance may be changed after the water recedes if the river water is laden 
with silts. Over an extended period riverine wetlands adjoining the channel may degenerate into terrace wetlands if the channel bed is deeply incised or the river water drops to such a low level that it reaches the wetlands only during flooding.

\section{Implications for Wetland Protection}

As illustrated in Figures 1-7, all the identified types of wetlands on the Plateau happen to be productive marshy or swampy meadows except the aquatic section of lacustrine wetlands. This coincidence raises serious implications for the rational utilization and proper protection of plateau wetlands. The Kobresia schoenoides wetlands on the Qinghai-Tibet Plateau are degradable through desiccation, periglacial processes, small mammals, and grazing by livestock (Miehe et al. 2011). The azonal K. schoenoides swamps have been widely degraded and replaced by grazing pastures. Degradation of plateau wetlands on the Qinghai-Tibetan Plateau has progressed since the 1960 s to become a widespread phenomenon (Zhang et al. 2011). How to make the maximum use of the wetland resources without compromising their ability for sustainable animal husbandry requires an in-depth scrutiny of their vulnerability. Whether a given type of plateau wetland is vulnerable to change is related closely to its position on a slope and in the watershed that ultimately governs the availability of water and moisture. Topographically, the seven types of plateau wetlands fall into three elevation ranges of upland, midland, and lowland (Table 1). Upland (alpine and piedmont) wetlands are the most vulnerable and sensitive to change owing to the steep topography, their limited physical size, and their confined catchment size. Having the steepest terrain among all the plateau wetlands, alpine wetlands are the most sensitive to degradation. The steep surface of piedmont wetlands with a lower water reserve makes them prone to degradation. The inefficient manner of recharge (e.g., subsurface flow) means that the low water reserve can be quickly depleted by excessive evaporation during droughts. This vulnerability is exacerbated by moisture loss through outflow. Reduction in soil moisture forces the former wetlands to degenerate into dry pastures. Such a high level of propensity to change requires that the grasslands be grazed at a low intensity level (e.g., rotation grazing), especially in the dry season so that moisture cannot be lost easily via evaporation. If degraded, the effect of degradation can be felt widely because of the steep terrain.

Midland wetlands (valley, floodplain, and terrace) tend to be productive grazing fields that have exhibited a wide range of resilience to degradation. Their vulnerability is governed by two opposite forces. On the one hand, their relatively abundant water reserve (except terrace wetlands) causes them to be insensitive to external change. On the other, they are favored by livestock for grazing due to the presence of nutritional species of grasses. Heavy grazing weakens their resistance to change and may turn the potential of degradation into a reality if moisture level drops to a certain threshold. Of the three, valley wetlands with a large water reserve and a level surface are the least prone to change and degradation. By comparison, terrace wetlands have suffered the most degradation (Figure 3). Some terrace wetlands have been degraded to such a degree that it is questionable whether they should still be called wetlands. Although the richer water reserve of floodplain wetlands makes them relatively resilient to change, care must be taken to restrict grazing to a sustainable level.

Of all the wetlands on the Plateau, low-land wetlands (lacustrine and riverine) are the most stable for two reasons. First, there is an abundant supply of water at such a low elevation. Thus, their water reserve cannot be depleted easily. Second, the topography is generally rather flat. Even if the wetlands themselves are degraded, the degradation will have a limited off-site impact (e.g., eroded soils are not carried far away). The most immediate threat to the health of lowland wetlands is the fluctuating water level of lakes and rivers. Lake and river floors exposed at a low water level may suffer from soil erosion, especially if covered with a layer of silt. At a higher water level, the wet grassland is turned into water with their grazing value destroyed. Thus, a healthy and stable water level should be maintained to prevent such a loss. Besides, it is also important to have a sound ecosystem in the upper catchment so that no silt from the river water will deposit over grassland during flooding. Of lacustrine wetlands, the 
terrestrial section is more vulnerable to change than its aquatic counterpart. The onshore section with a lower water reserve is easily degradable if not adequately recharged during droughts. During floods dwarf seedlings are prone to perish and difficult to recover after the water has receded. In either case the impact is mostly localized. Therefore, it is necessary to control grazing to a level reflective of this propensity.

\section{Conclusions}

A number of classification systems have been devised for inventorying wetlands around the world. However, none of them are deemed suitable for the Qinghai-Tibet Plateau that is characterized by a low annual temperature and a low rainfall regime. Here wetlands are distributed at a wide range of elevations from mountain sides to lowlying valleys, all being fragile and sensitive to external changes. It is important to recognize and classify these wetlands in order to devise targeted measures to protect them from degradation. The currently adopted criteria of wetland classification, such as landform and topography, origins, substrate types, hydrology, vegetation, nature and amount of water, soil properties, and nutrient status, are incompetent in classifying plateau wetlands as they are unable to shed light on their propensity for degradation. This deficiency is overcome with the proposed geomorphic-centered perspective that takes hydrology and landscape position into implicit consideration. According to this perspective, all wetlands on the Plateau fall into seven types of alpine, piedmont, valley, terrace, floodplain, and lacustrine, riverine on the order of descending elevation. They are spatially juxtaposed but connected hydrologically. Their vulnerability is best assessed by aggregating them into three elevation ranges of upland (alpine and piedmont wetlands), midland (valley, floodplain, and terrace

\section{References}

\footnotetext{
Bedford BL, and Preston EM (1988) Developing the scientific basis for assessing cumulative effects of wetland loss and degradation on landscape functions: Status, perspectives, and prospects. Environmental Management 12(5): 751-771. DOI: 10.1007/BFo1867550
}

wetland), and lowland (riverine and lacustrine wetlands). As elevation lowers, the source zone of wetland replenishment expands while the water reserve in a wetland rises, causing the wetlands to respond to external changes more sluggishly and more resistant to degradation.

This geomorphic-centered perspective on plateau wetlands is significant as it is indicative of their potential for change. Differentiation of wetlands by their geomorphic features has practical values as varying grazing intensity levels should be applied to marshy and swampy meadows of different water reserves and different means of hydrological replenishment. More importantly, it provides valuable insights into their risk of degradation, and the need for their effective protection so as not to compromise their sustainability for animal husbandry. This perspective improves our understanding of the diversity and vulnerability of different wetlands on the Plateau, a prerequisite for their rational exploitation and effective protection.

\section{Acknowledgements}

This research was supported by Program of International S\&T Cooperation, the Ministry of Science and Technology of the People's Republic of China (Grant No. 2011DFA20820), International Science \& Technology Cooperation Program of China, MOST (Grant No. 2011DFG93160), the Qinghai Science and Technology Department (Grant No. 2009-J-806) and Department of International Exchange \& Cooperation of the Ministry of Education (Grant Nos. 2009-1599, 2010-1595). Gary Brierley acknowledges support as a Distinguished Visiting Fellow at the Chinese Academy of Sciences. Qing-yu CHEN and Yu-Lin SONG from Qinghai University provided considerable assistance during the field trip of this study.
Brinson MM (1993) A Hydrogeomorphic Classification for Wetlands. WRP-DE-4. Vicksburg, MS: U.S. Army Engineer Waterways Experiment Station.

Brooks RP, Brinson MM, Havens KJ, et al. (2011) Proposed hydrogeomorphic classification for wetlands of the Mid- 
Atlantic Region, USA. Wetlands 31(2): 207-219. DOI: 10.1007/s13157-011-0158-7

Clausen JC, Ortega IM, Glaude CM, et al. (2006) Classification of wetlands in a Patagonian National Park, Chile. Wetlands 26: 217-229. DOI: 10.1672/0277-5212(2006)26[217:COWIAP] 2.0.CO;2

Costa LT, Farinha JC, Hecker N, et al. (1996) Mediterranean Wetland Inventory: A Reference Manual. MedWet / Instituto da Conservacão da Natureza / Wetlands International Publication, Volume I.

Cowardin LM, Carter V, Golet FC, et al. (1979) Classification of Wetlands and Deepwater Habitats of the United States. US Fish and Wildlife Service FWS/OBS-79/31. Washington D.C., USA.

Deng ML, Tian K, Yang YX, et al. (2010) Variation of landscape of the ruo ergai national reserve of plateau wetland and its driving forces. Journal of Ecology and Rural Environment 26(1): 58-62. (In Chinese)

Environmental Council (1983) Wetlands: A Diminishing Resource. Water and Soil Miscellaneous Publication No. 58.

Espinar JL, and Serrano L (2009) A quantitative hydrogeomorphic approach to the classification of temporary wetlands in the doñana national park (SW Spain). Aquatic Ecology 43:323-334. DOI: 10.1007/s10452-007-9162-7

Forman RTT, and Godron M (1986) Landscape Ecology. John Wiley \& Sons, New York. pp 619.

Finlayson CM, and AG van der Valk (1995) Wetland classification and inventory: A summary. Vegetatio 118: 185192. DOI: $10.1007 /$ BFoo0 45199

Hebert PDN (ed.) (2002) Canada's Aquatic environments, Chapter 2: Classification of Wetlands, http://www.aquatic. uoguelph.ca/wetlands/chclass.htm (accessed 28 April 2011).

Hefner JM, and Storrs CG (1994) Classification and inventory of wetlands in the southern Appalachian region. Water, Air, \& Soil Pollution 77: 209-216. DOI: 10.1007/BFo0478419

Kingsford RT (2000) Ecological impacts of dams, water diversions and river management on floodplain wetlands in Australia. Austral Ecology 25: 109-127. DOI: 10.1111/j.14429993.2000.tbooo12.x

Miehe G, Miehe S, Bach K, et al. (2011) Plant communities of central Tibetan pastures in the Alpine Steppe/Kobresia pygmaea ecotone. Journal of Arid Environments 75(8): 711723. DOI: 10.1016/j.jaridenv.2011.03.001

Morant PD (1983) Wetland classification: towards an approach for southern Africa. Journal of Limnology of the Society of South Africa 9(2): 76-84.

O'Brien AL (1988) Evaluating the cumulative effects of alteration on New England wetlands. Environmental Management 12:627-636. DOI: 10.1007/BFo1867541

Ramsar Convention Bureau (1997) The Ramsar Convention Manual: a Guide to the Convention on Wetlands (Ramsar,
Iran, 1971) ( $2^{\text {nd }}$ ed). Ramsar Convention Bureau. Gland. Switzerland.

Robertson HA, and Fitzsimons JA (2004) Hydrology or floristics? Mapping and classification of wetlands in Victoria, Australia, and implications for conservation planning. Environmental Management 34: 499-507. DOI: 10.1007/ s00267-003-0185-0

Semeniuk CA (1987) Wetlands of the Darling System - a geomorphic approach to habitat classification. Journal Royal Society of Western Australia 69: 95-112.

Semeniuk CA, Semeniuk V, Cresswell ID, et al. (1990) Wetlands of the Darling System, southwestern Australia: a descriptive classification using vegetation pattern and form. Journal Royal Society of Western Australia 72: 109-121.

Semeniuk C (2007) The Becher wetlands, a Ramsar site (Wetlands: Ecology, Conservation and Management), Springer. p 695 .

Smith RD, Amman A, Bartoldus C, et al. (1995) An Approach for Assessing Wetland Functions Based on Hydrogeomorphic Classification, Reference Wetlands, and Functional Indices. WRP-DE-9. Vicksburg, MS: U.S. Army Engineer Waterways Experiment Station.

Stander EK, and Ehrenfeld JG (2009) Rapid assessment of urban wetlands: Do hydrogeomorphic classification and reference criteria work? Environmental Management 43: 725742. DOI: $10.1007 /$ so0267-008-9211-6

Thompson K (1987) Annotated Bibliography of New Zealand Peat and Peatlands. Water and Soil Miscellaneous Publication No. 114. National Water and Soil Conservation Organisation, Wellington. p 164.

Ward JC, and Lambie JS (1999) Monitoring Changes in Wetland Extent: Environmental Performance Indicators for Wetlands. Final Report - Project Phase 1. Lincoln Environmental: Canterbury. p 37.

Wang X (2000) Chapter 15: High-cold scrubs and meadow zone. In: Zheng D, Zhang Q, Wu S. (editors), Mountain Geoecology and Sustainable Development of the Tibetan Plateau, Kluwer Academic Publishers. pp 303-325.

Zhang Y, Wang G, Wang Y (2011) Changes in alpine wetland ecosystems of the Qinghai-Tibetan plateau from 1967 to 2004. Environmental Monitoring and Assessment 180(1-4): 189-199. DOI: 10.1007/s10661-010-1781-0

Zheng D, Zhang R, Yang Q (1979) On the natural zonation in the Qinghai-Xizang Plateau. Acta Geographica Sinca 34(1): 1-11.

Zhou H, Zhao X, Tang Y, et al. (2005) Alpine grassland degradation and its control in the source region of the Yangtze and Yellow Rivers, China. Grassland Science 51: 191-203. DOI: 10.1111/j.1744-697x.2005.00028.x

Zhou H, Zhou L, Liu W, et al. (2003) Study on grassland degradation and strategies for the sustainable development of the livestock raising industry in Guoluo Prefecture of Qinghai. Pratacultural Science 2O(10): 19-25. 